Кушнір С.O.

кандидат економічних наук, доцент, доцент кафедри фінансів, банківської справи та страхування,

Запорізький національний університет

Журавльова А.К.

Запорізький національний університет

\title{
ІНВЕСТИЦІЇ В СІЛЬСЬКОГОСПОДАРСЬКУ ГАЛУЗЬ УКРАЇНИ: РЕАЛІЇ ТА ПЕРСПЕКТИВИ У ЗВ'ЯЗКУ 3 ВІДКРИТТЯМ РИНКУ ЗЕМЛІ
}

У статті розглянуто зміст інвестицій у науковій літературі. Проаналізовано динаміку прямих іноземних інвестицій в економіку Украӥни. Досліджено структуру та динаміку прямих інвестицій в Украйну за краӥнами походження. Розглянуто структуру прямих іноземних інвестицій в Украйну за видами економічної діяльності та визначено частку інвестицій у сільське господарство Украӥни. Проаналізовано основні економічні, правові, фінансові, політичні, сочіальні негативні чинники, які впливають на інвестиційний клімат галузі сільського господарства України. Проаналізовано зміст нормативно-правової бази шодо земельної реформи в України, а саме основні пункти, які стосуються відкриття ринку землі, який дає змогу купувати та продавати землю. Визначено напрями сільського господарства, які пери за все потребують інвестиційної підтримки, акиентовано увагу на необхідності підвищеного контролю за виконанням норм закону про землю, особливо щзодо кінцевих бенефіціарів покупиів.

Ключові слова: інвестииї̈, іноземні інвестииї, ринок землі, інвестиційна привабливість, інвестиційний клімат, сільське господарство, земельні ресурси.

Постановка проблеми. Сьогодні є актуальним вивчення проблеми інвестиційної діяльності у сільське господарство та земельні ресурси, особливо після відкриття ринку землі. Це дає поштовх переосмислити можливість реалізації та вдосконалення природно-економічного потенціалу сільської галузі України. Між тим реалізація потенціалу сільськогосподарської галузі дає можливості підвищити рейтинг України в політичних та економічних відносинах 3 іншими країнами. Залучення інвестицій у сільське господарство допоможе відновити цю сферу та сформувати середній клас у суспільстві.

Аналіз останніх досліджень і публікацій. Проблеми залучення інвестицій у сільськогосподарську 
галузь вивчала велика кількість науковців, серед яких можна назвати таких, як А.С. Музиченко, Г.В. Козаченко, М.I. Кісіль, М.Ю. Кожем'якін, А.А. Пересада, Ф.В. Федоренко, В.Г. Андрійчук, О.Г. Білорус, Б.В. Губський, В.П. Савчук, Ю.О. Лупенко, М.Й. Малік, Г.В. Спаський, О.Г. Шпикуляк [3; 5; 9]. Науковці акцентують увагу на тому, що саме інвестиційна складова частина є рушієм нашої економіки й сприятиме розвитку вітчизняного сільського господарства та інтеграції національної економіки у європейський простір.

Мета статті полягає в аналізі інвестиційних потоків у сільське господарство України, розгляді сучасного інвестиційного клімату та визначенні перспективних напрямів інвестування 3 урахуванням ризиків для сучасного інвестора.

Виклад основного матеріалу. Інвестиції - це один iз ключових чинників економічного зростання, довгострокові та короткострокові вкладення капіталу, що складаються з капітальних витрат (капітальних вкладень); витрат, пов'язаних з приростом оборотного капіталу (під час розширення виробництва) або оборотним капіталом в повному обсязі, необхідним для запуску виробництва (під час створення нових виробництв), а також витрат, необхідних для підготовки інвестиційного проекту [9, с. 7].

У Законі України «Про інвестиційну діяльність» інвестиції визначаються як усі види майнових та інтелектуальних цінностей, що вкладаються в об'єкти підприємницької та інших видів діяльності, в результаті чого створюється прибуток (доход) або досягається соціальний ефект [1, с. 1$]$.

Ю.О. Лупенко вважає, що інвестиційні процеси у сільському господарстві останнім часом різко загальмувалися внаслідок скорочення фінансових можливостей інвесторів і держави. Відновлення позитивної динаміки інвестицій вимагає вжиття радикальних заходів щодо підвищення інвестиційної привабливості галузі та якнайшвидшої макроекономічної стабілізації у державі [5, с. 62].

Розглянемо детальніше показники обсягу інвестицій і галузі, в які найбільше вкладають коштів на противагу сільському господарству.

Як видно з даних табл. 1, політичні зміни в Україні у 2013-2014 роках призвели до різкого падіння обсягу інвестування в Україну, у 2015-2016 роках інвестиції почали поступове зростання. Однак ефективність економічних реформ, що відбулись у 2017-2018 роках, призвела до скорочення надходжень прямих іноземних інвестицій, обсяг яких у 2018 році порівняно з 2017 роком зменшився майже на 30\%. Незначне збільшення надходжень у 2019 році, а саме лише на 153 млн. дол. США, або на 6,9\%, продовжує свідчити про недовіру іноземних інвесторів до можливостей стабільного ведення бізнесу та поліпшення інвестиційного клімату в країні.

Дані табл. 2 показують, що у 2014 році найбільше надходжень було з Кіпру (30,8\%) та Нідерландів (16,4\%). Натомість у 2019 році частка інвестицій 3 Кіпру дещо знизилась, а частка інвестування Нідерландів зростає. Також можна помітити тенденції до зростання інвестицій з Великобританії та Швейцарії. Також можна звернути увагу на те, що дещо зростають інвестиції з Російської Федерації та 3 інших країн $(21,9 \%)$.

Однак європейські країни не прагнуть залучати великі кошти в економіку України (рис. 1).

Аналіз структури інвестиційної діяльності за видами економічної діяльності показав таке.

Отже, можна звернути увагу на те, що у 2015 році перше місце за вливаннями прямих іноземних інвестицій посідала промисловість, потім йшли оптова та роздрібна торгівля, фінансова та страхова діяльність. Натомість у 2019 році обсяги інвестицій зросли тільки у промисловість та оптову й роздрібну торгівлю, але трійку замикають операції 3 нерухомим майном. $€$ сфери, в яких, навпаки, впали обсяги іноземних інвестицій. До них можна віднести будівництво, фінансову та страхову діяльність, професійну, наукову та технічну діяльність, інші види економічної діяльності. Отже, інвестиції, які надходять у сільське господарство, є мізерними.

Існує низка економічних, правових, фінансових, політичних, соціальних негативних чинників, які впливають на інвестиційний клімат галузі сільського господарства України.

На нашу думку, до правової сфери ризику іноземних інвестицій в сільське господарство можна віднести корупцію; незахищені права власності, рейдерство; централізацію влади, тобто неможливість регіонів конкурувати у сфері залучення інвестицій; примус

Таблиця 1 - Надходження прямих інвестицій в Україну

\begin{tabular}{|c|c|c|c|c|}
\hline \multirow{2}{*}{ Рік } & $\begin{array}{c}\text { Прямі іноземні } \\
\text { інвестиції, } \\
\text { млн. дол. США }\end{array}$ & $\begin{array}{c}\text { Показники динаміки (до попереднього року) } \\
\text { (зменшення), млн. дол. США }\end{array}$ & $\begin{array}{c}\text { абсолюкнс динаміки, \% } \\
\text { темп приросту } \\
\text { (зменшення), \% }\end{array}$ \\
\hline 2010 & 6495 & 1679 & 134,9 & 34,9 \\
\hline 2011 & 7207 & 712 & 111,0 & 11,0 \\
\hline 2012 & 8401 & 1194 & 116,6 & 16,6 \\
\hline 2013 & 4499 & -3902 & 53,6 & $-46,4$ \\
\hline 2014 & 410 & -4089 & 9,1 & $-90,9$ \\
\hline 2015 & 2961 & 2551 & 722,2 & 622,2 \\
\hline 2016 & 3130 & 169 & 105,7 & 5,7 \\
\hline 2017 & 3130 & 169 & $105,7 \%$ & 5,7 \\
\hline 2018 & 2202 & -928 & $70,4 \%$ & $-29,6$ \\
\hline 2019 & 2355 & 153 & $106,9 \%$ & 6,9 \\
\hline
\end{tabular}

Джерело: складено на основі джерел [6;8] 
бізнесу до покриття фінансових проблем регіону під приводом його залучення до вирішення соціальних питань; тиск на бізнес з боку органів влади; неврегульованість питання державно-приватного партнерства; часті зміни законодавства невиконання законів; незавершеність законотворчого процесу та неможливість втілення прийнятих законів [8, с. 36].

До економічних ризиків можна віднести монополізацію економіки; низьку платоспроможність значної частини населення; низький попит на внутрішньому ринку; низький попит на зовнішніх ринках; низький рівень ділової активності; залежність виробництва від тимчасових коливань попиту; залежність виробництва від природних ресурсів; тінізацію економічних відносин [3, с. 80].

До фінансових ризиків належать податкове навантаження та дефіцит державного бюджету, високі кредитні ставки, неповернення ПДВ [5, с. 29].

До інших, не менш вагомих факторів гальмування іноземних інвестицій у сільське господарство можна віднести політичну нестабільність; безробіття; низьку кваліфікацію випускників управлінських та маркетингових спеціальностей; брак часових та фінансових ресурсів для підвищення кваліфікації працівників на підприємствах; низький рівень володіння молоді іноземними мовами; слабкий розвиток інфраструктури; погану екологічну ситуацію $[9$, с. 16$]$.

Між тим, на думку Л.О. Чіп, існує чимало інших негативних факторів, котрі знижують інвестиційну привабливість аграрного сектору України, передусім до них можна віднести низький рівень захисту прав землевласників та землекористувачів, недостатне наповнення кадастрового реєстру та реєстру речових вправ, низку неузгодженостей між ними, налагодження інфраструктури, вантажних перевезень [11, с. 142].

Навесні 2020 року Верховною Радою України було прийнято закон щодо відкриття ринку землі, який дає змогу купувати та продавати землю фізичним особам та українським підприємцям, державі. Згідно із Законом України «Про внесення змін до деяких законодавчих актів України щодо обігу земель сільськогосподарського призначення» від 31 березня 2020 року № 552-IX (далі - Закон) [2] внесено зміни до Земельного кодексу України, які стосуються набуття права власності на землі сільськогосподарського призначення, тобто можливість операцій продажу таких земель.

Так, змінами, внесеними до статті 130 Земельного кодексу, визначено перелік осіб, які можуть набувати права власності на земельні ділянки сільськогосподарського призначення, а також визначено, хто не має такого права. Так, «іноземцям, особам без громадянства та юридичним особам заборонено набувати частки у статутному (складеному) капіталі, акції, паї,

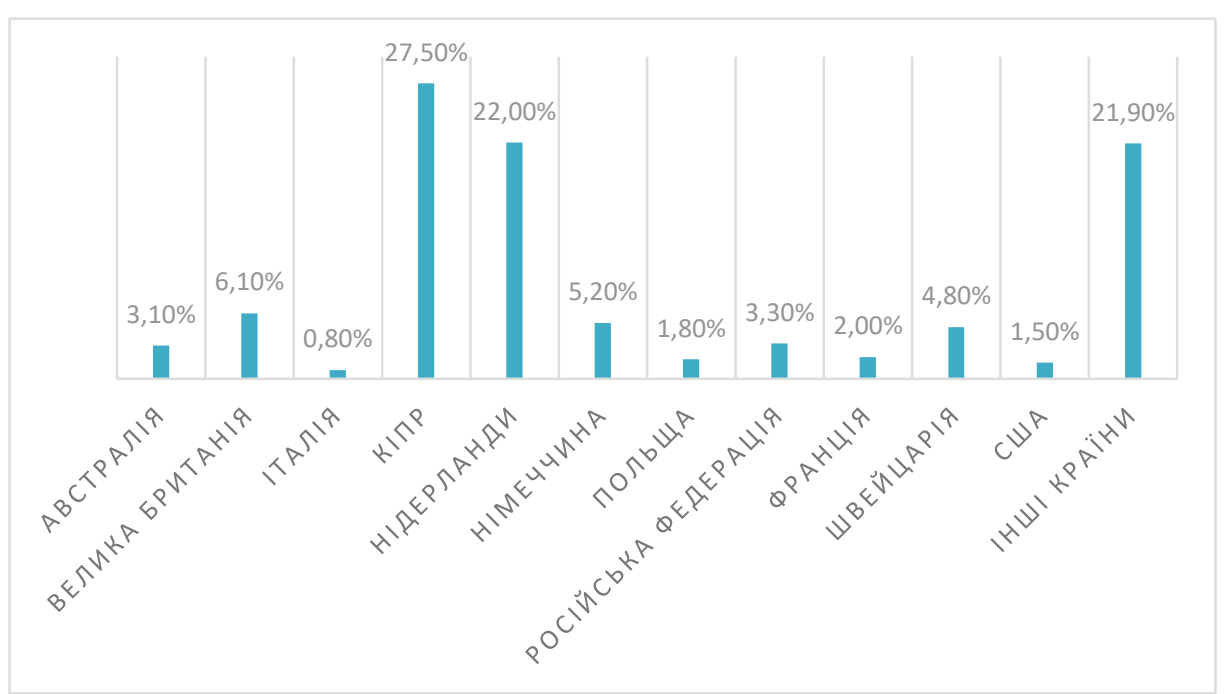

Рисунок 1 - Структура прямих іноземних інвестицій в економіку України (за країнами світу), 2019 рік, \%

Таблиця 2 - Структура прямих іноземних інвестицій в економіку України (за країнами світу)

\begin{tabular}{|l|c|c|c|c|c|c|}
\hline \multirow{2}{*}{\multicolumn{1}{|c|}{ Країна }} & \multicolumn{6}{|c|}{ Структура іноземних інвестицій на 1 січня, \% } \\
\cline { 2 - 7 } & $\mathbf{2 0 1 4}$ рік & $\mathbf{2 0 1 5}$ рік & $\mathbf{2 0 1 6}$ рік & $\mathbf{2 0 1 7}$ рік & $\mathbf{2 0 1 8}$ рік & $\mathbf{2 0 1 9}$ рік \\
\hline Австралія & 4,8 & 3,9 & 3,6 & 3,4 & 3,2 & 3,1 \\
\hline Велика Британія & 4,8 & 3,9 & 5,6 & 5,9 & 6,0 & 6,1 \\
\hline Італія & 0,8 & 0,8 & 0,7 & 0,7 & 0,8 & 0,8 \\
\hline Кіпр & 30,8 & 30,7 & 30,8 & 29,1 & 27,7 & 27,5 \\
\hline Нідерланди & 16,4 & 18,1 & 19,0 & 21,6 & 22,3 & 22,0 \\
\hline Німеччина & 8,7 & 6,3 & 5,2 & 5,2 & 5,4 & 5,2 \\
\hline Польща & 1,7 & 2,1 & 2,1 & 2,0 & 1,9 & 1,8 \\
\hline Російська Федерація & 6,0 & 2,0 & 1,3 & 2,5 & 3,1 & 3,3 \\
\hline Франція & 2,9 & 3,9 & 4,0 & 3,3 & 2,7 & 2,0 \\
\hline Швейцарія & 2,1 & 3,4 & 4,3 & 4,9 & 4,6 & 4,8 \\
\hline США & 2,0 & 2,1 & 2,2 & 2,0 & 1,7 & 1,5 \\
\hline Інші країни & 19,0 & 22,8 & 21,2 & 19,4 & 20,6 & 21,9 \\
\hline Всього & 100 & 100 & 100 & 100 & 100 & 100 \\
\hline
\end{tabular}

Джерело: складено на основі джерел [6; 8; 10$]$ 
Таблиця 3 - Структура прямих іноземних інвестицій в Україну за видами економічної діяльності

\begin{tabular}{|l|c|c|c|c|c|}
\hline \multirow{2}{*}{\multicolumn{1}{|c|}{ Вид економічної діяльності }} & \multicolumn{5}{|c|}{ Структура іноземних інвестицій на 1 січня, \% } \\
\cline { 2 - 6 } & $\mathbf{2 0 1 5}$ рік & $\mathbf{2 0 1 6}$ рік & $\mathbf{2 0 1 7}$ рік & $\mathbf{2 0 1 8}$ рік & $\mathbf{2 0 1 9}$ рік \\
\hline Промисловість & 31,5 & 30,8 & 31,8 & 32,6 & 33,0 \\
\hline Сільське господарство & 1,5 & 1,6 & 1,5 & 1,6 & 1,7 \\
\hline Будівництво & 3,5 & 3,2 & 3,1 & 3,0 & 2,9 \\
\hline Фінансова та страхова діяльність & 15,1 & 13,5 & 12,4 & 11,1 & 10,9 \\
\hline Інформація та телекомунікації & 6,4 & 6,5 & 6,4 & 6,6 & 6,8 \\
\hline Оптова та роздрібна торгівля & 15,9 & 15,9 & 16,1 & 16,4 & 16,7 \\
\hline Операції з нерухомим майном & 13,1 & 11,7 & 12,1 & 12,3 & 12,4 \\
\hline Професійна, наукова та технічна діяльність & 7,3 & 7,0 & 6,8 & 6,4 & 6,2 \\
\hline Інші види економічної діяльності & 6,7 & 9,8 & 9,8 & 10,0 & 9,3 \\
\hline Усього & 100 & 100 & 100 & 100 & 100 \\
\hline
\end{tabular}

Джерело: складено на основі джерел [6; 8; 10]

членство у юридичних особах (крім як у статутному (складеному) капіталі банків), які є власниками земель сільськогосподарського призначення. Цей абзац втрачає чинність за умови та 3 дня схвалення на референдумі рішення, визначеного абзацом восьмим цієї частини» [2]. На аналогічних правах також зазначено умови набуття права власності на земельні ділянки сільськогосподарського призначення юридичними особами, створеними і зареєстрованими за законодавством України, учасниками (засновниками) або кінцевими бенефіціарними власниками яких є особи, які не $\epsilon$ громадянами України.

Також у статті 130 Земельного кодексу України перелічено вісім категорій осіб, яким забороняється продаж земельних ділянок сільськогосподарського призначення, зокрема за схвалення на референдумі. Серед таких слід назвати продаж земельних ділянок, розташованих ближче 50 кілометрів від державного кордону України, придбання юридичними особами, кінцеві бенефіціарні власники якої є особами держави-окупанта та агресора, або зареєстровані у державах, включених Міжнародною групою з протидії відмиванню брудних грошей (FATF) до списку держав, що не співпрацюють у сфері протидії відмиванню доходів, одержаних злочинним шляхом, або іноземні держави, або коли неможливо встановити кінцевого бенефіціарного власника, або які зареєстровані в офшорних зонах, або належать чи належали до терористичних організацій, стосовно яких застосовано спеціальні економічні санкції.

Частиною 2 статті 130 Земельного кодексу України передбачається, що загальна площа земельних ділянок сільськогосподарського призначення у власності громадянина України не може перевищувати десяти тисяч гектарів, у власності юридичної особи (крім банків) вона не може перевищувати загальної площі земельних ділянок сільськогосподарського призначення, які можуть перебувати у власності всіх іiі учасників (членів, акціонерів), але не більше десяти тисяч гектарів.

За Законом передбачено часові обмеження, а саме пунктом 15 статті 145 зазначено, що «до 1 січня 2024 року загальна площа земельних ділянок сільськогосподарського призначення у власності громадянина України не може перевищувати ста гектарів. Зазначене обмеження не поширюється на земельні ділянки, набуті у власність громадянином до набрання чинності цим підпунктом».
Проте, незважаючи на прийняття Закону, інвестиційний клімат України нині не є комфортним. Однак, незважаючи на негативні фактори, слід покращувати партнерство та розвивати залучення інвестицій у сільське господарство.

Перш за все інвестиційної підтримки прагнуть державні сільськогосподарські підприємства, підприємства приватної форми власності $з$ широким колом учасників, фермерські господарства. Інвестиції потрібні аграрному сектору та державі загалом задля відтворення родючості грунтів, забезпечення продовольчої безпеки держави, соціального захисту та забезпечення нормальних умов для сільського населення.

Інвестиції необхідні для переоснащення виробництва, оздоровлення підприємств, будівництва ферм, ангарів та систем складських приміщень, що допоможе збільшити обсяги виробництва та підвищити продуктивність, сприятиме розвитку соціальної сфери та інфраструктури.

Сьогодні актуальною проблемою постає зрошення земель сільськогосподарського призначення, адже брак опадів, безсніжних зим впливає на зниження врожаїв, тому інвестиції в оснащення земель системами зрошення нині $\epsilon$ необхідністю.

Звичайно, для відкриття ринку землі в такому вигляді, як він діє сьогодні в цивілізованих європейських країнах, потрібно докласти багато зусиль. Система має працювати прозоро за допомогою аукціонів і не мати корупційної складової частини. Велике значення має дієвість українського законодавства та судів. Навіть після того, як земельний ринок запрацює, повинні бути злагоджені дії між реєстрами та інститутами в правовому полі. Проаналізовані зміни можуть послугувати поштовхом для подальшого розвитку економіки держави, але за умови подолання корупції та налагодження роботи чесних безпристрасних судів.

Висновки. Сприятливі природно-кліматичні умови, родючість грунтів, вигідне транспортно-географічне розташування, наявність робочої сили, на перший погляд, мають сприяти залученню інвестицій у сільське господарство, але існує низка негативних факторів, які стримують ці процеси в Україні. Налагодження інвестиційного клімату у сфері АПК дасть змогу розширити ринки збуту продукції, збільшити обсяги виробництва, підвищити ефективність науко- 
вого потенціалу сільськогосподарських підприємств, а також повернути населення до сільської місцевості, вдосконалити інфраструктуру, збільшити кількість робочих місць

Отже, прийняття земельної реформи має великий потенціал, яким потрібно правильно скористатись, оскільки досить важливим є контроль за неможливістю продажу землі іноземцям чи можновладцям задля реалізації їх потреб. Відкриття ринку землі має забезпечити конкурентоздатність України у сфері АПК і дати можливість малому та середнього бізнесу розвиватись.

\section{Список використаних джерел:}

1. Спаський Г.В. Інвестиційна привабливість сільського господарства. Економіка АПК. 2018. № 2. С. 30-36.

2. Про інвестиційну діяльність : Закон України від 20 жовтня 2019 року № 1560-XII. URL: http://zakon4.rada.gov.ua/laws/ show/1560-12 (дата звернення: 13.05.2020).

3. Лупенко Ю.О., Малік М.Й., Шпикуляк О.Г. Інноваційне забезпечення розвитку сільського господарства України: проблеми та перспективи. Київ : ННЦ «ІАЕ», 2017. 516 с.

4. Офіційний сайт Державної служби статистики України. URL: http://www.ukrstat.gov.ua (дата звернення: 13.05.2020).

5. Самотоєнкова О.В. Економічна статистика : навчальний посібник. Одеса : ОДЕУ, 2019. 182 с.

6. Статистичний щорічник України за 2019 рік. Київ : Держстат України, 2020. 660 с.

7. Кісіль М.І. Інвестиційне забезпечення розвитку сільського господарства. Стратегічні напрями розвитку сільського господарства України на період до 2020 року. Київ : ННЦ «IAЕ», 2018. С. 76-80.

8. Чіп Л.О. Особливості інвестиційного клімату в Україні. Вісник Полтавської державної аграрної академії. 2018. № 3. C. $142-146$.

9. Про внесення змін до деяких законодавчих актів України щодо обігу земель сільськогосподарського призначення : Закон України від 31 березня 2020 року № 552-IX. URL: http://search.ligazakon.ua/1_doc2.nsf/link1 (дата звернення: 13.05.2020).

10. Концепція Державної цільової програми розвитку аграрного сектору економіки на період до 2020 року. URL: http:// minagro.gov.ua/node/16822 (дата звернення: 13.05.2020).

11. Савельєв Є.В. Пріоритети у реформуванні української економіки. Економіка України. 2015. № 5. C. 79-89. URL: http:// nbuv.gov.ua/UJRN/EkUk_2015_5_8 (дата звернення: 13.05.2020).

12. Самотоєнкова О.В. Економічна статистика : навчальний посібник. Одеса : ОДЕУ, 2019. 182 с.

\section{References:}

1. Spassky G.V. (2018). Investytsiyna pryvablyvist' sil's'koho hospodarstva. [Investment attractiveness of agriculture]. Economics of agro-industrial complex, no. 2, pp. 30-36.

2. On investment activity: Law of Ukraine 20.10.2019 roku № 1560-XII. URL: http://zakon4.rada.gov.ua/laws/show/1560-12 [in Ukrainian].

3. Lupenko Y.O, Malik M.Y., Shpikulyak O.G. (2017) Innovatsiyne zabezpechennya rozvytku sil's'koho hospodarstva Ukrayiny: problemy ta perspektyvy [Innovative support of agricultural development of Ukraine: problems and prospects]. Kyiv : NSC "IAE" [in Ukrainian].

4. Ofitsiynyy sayt Derzhavnoyi sluzhby statystyky Ukrayiny [Official site of the State Statistics Service of Ukraine]. URL: http:// www.ukrstat.gov.ua [in Ukrainian].

5. Samotoenkova O.V. (2019) Ekonomichna statystyka : navch. posib. [Economic statistics : textbook. way.]. Odessa : ODEU [in Ukrainian].

6. Statystychnyy shchorichnyk Ukrayiny za 2019 rik. [Statistical Yearbook of Ukraine for 2019]. Kyiv : State Statistics Service of Ukraine [in Ukrainian].

7. Kisil' M.I. (2018) Investytsiyne zabezpechennya rozvytku sil's'koho hospodarstva. [Investment support for agricultural development]. Strategic directions of agricultural development of Ukraine for the period up to 2020. Kyiv : NSC "IAE", pp. 76-80.

8. Chip L.O. (2018) Osoblyvosti investytsiynoho klimatu v Ukrayini [Features of the investment climate in Ukraine]. Bulletin of the Poltava State Agrarian Academy, no. 3, pp. 142-146.

9. On Amendments to Certain Legislative Acts of Ukraine Concerning the Circulation of Agricultural Lands: Law of Ukraine 31.03.2020 roku № 552-IX. URL: http://search.ligazakon.ua/1_doc2.nsf/link1 [in Ukrainian].

10. Kontseptsiya Derzhavnoyi tsil'ovoyi prohramy rozvytku ahrarnoho sektoru ekonomiky na period do 2020 roku. [The concept of the State target program for the development of the agricultural sector of the economy until 2020]. URL: http://minagro.gov.ua/ node/16822 [in Ukrainian].

11. Savel'yev Y.V.(2015) Priorytety u reformuvanni ukrayins'koyi ekonomiky. [Savelyev EV Priorities in reforming the Ukrainian economy]. Ukraine economy, no. 5, pp. 79-89. URL: http://nbuv.gov.ua/UJRN/EkUk_2015_5_8 [in Ukrainian].

12. Samotoyenkova O.V. (2019) Ekonomichna statystyka : navch. posib. [Economic statistics : textbook. way.]. Odesa : ODEU [in Ukrainian]. 
Kushnir Svitlana, Zhuravlova Anastasiia

Zaporizhia National University

\section{INVESTMENT IN THE AGRICULTURAL INDUSTRY OF UKRAINE: REALITIES AND PROSPECTS IN CONNECTION WITH THE OPENING OF THE LAND MARKET}

The relevance of the article is due to the special importance of understanding the need to attract investment in agriculture, which are promising investments and can bring a stable long-term income. The article considers the content of investments in the scientific literature. The dynamics of foreign direct investment in the economy of Ukraine is analyzed. The structure and dynamics of direct investments in Ukraine by countries of origin are researched. The structure of foreign direct investment in Ukraine by types of economic activity is considered and the share of investments in agriculture of Ukraine is determined. The main economic, legal, financial, political, social negative factors that affect the investment climate of Ukraine's agriculture are analyzed. The content of the legal framework for land reform in Ukraine is analyzed, namely the main points concerning the open market of the country, which can buy and sell land. Areas of agriculture that primarily need investment support are identified, and the need for increased control over the implementation of the law on land is emphasized, especially with regard to the final beneficiaries of buyers. An assessment of the law on the opening of the land market in Ukraine is made, and economic, political, financial risks of the investment climate in this area are analyzed. The directions of investment activity in small agrarian enterprises are characterized. The focus is on the problem of insufficient funding of small agricultural enterprises and the impact of underfunding on the reproduction of soil fertility, food security of the state, social protection and ensuring normal conditions for the rural population. Emphasis is placed on the positive impact of attracting foreign investment in agriculture, such as the ability to expand markets, increase production, increase the efficiency of the scientific potential of agricultural enterprises, and increase the number of jobs. It is determined that the main volume of foreign direct investment in recent years is concentrated in industry and wholesale and retail trade, while in other industries there is a decline.

Key words: investments, foreign investments, land market, investment attractiveness, investment climates, agriculture, land resources.

JEL classification: K11, O13, P25, P28, Q15 